\title{
Three-dimensional modeling of Pennsylvanian sandstone units in the mature Dudley oil field, Illinois, USA
}

\author{
Jordan M. Martin ${ }^{1}$ David H. Malone ${ }^{1}$
}

Received: 8 April 2016/ Accepted: 25 November 2016/Published online: 9 December 2016

(C) The Author(s) 2016. This article is published with open access at Springerlink.com

\begin{abstract}
The purpose of this research is to better understand the Dudley Pool, a small, mature oil field in the Illinois Basin, USA by incorporating old geologic and geophysical data into modern petrophysical modeling software. The research focused on three-dimensional subsurface modeling of stratigraphy, structure, and porosity, to establish a more thorough understanding of oil occurrence at the Dudley Pool. This research also discusses the efficacy of three-dimensional modeling as an effective tool for evaluating, and potentially modifying, production efforts in mature petroleum fields with limited and/or poor-quality data. The modeling and calculations were completed using Petrel. Well information from all wells drilled within a one mile collar of the field was collected. The model generated contour maps, thickness maps, a facies model, cross sections, core logging and a porosity model. The project established that the Dudley Pool is part of a major channel system heading southeast toward the interior of the Illinois Basin and, thus, may present additional resources for exploitation beyond the current production limit of the field. Isopach and structure contour trends indicate that areas to the northeast are targets for future exploration and development of the Dudley Pool.
\end{abstract}

Keywords Petrophysical modeling - Illinois basin . Pennsylvanian · Dudley pool

David H. Malone

dhmalon@ilstu.edu

Jordan M. Martin

jordan.martin.1986@gmail.com

1 Department of Geography-Geology, Illinois State University, Normal, IL 61790-4400, USA

\section{Introduction}

The purpose of this study is to better understand the Dudley Pool, a small, mature oil field in the eastern Illinois Basin, USA using existing geologic borehole and geophysical data. This research focused on three-dimensional subsurface modeling of the local stratigraphy, structure, and porosity, to establish a more thorough understanding of the oil occurrence at Dudley.

There are two distinct types of 3D models; the stratigraphic forward model and the three-dimensional (3D) geologic model. The stratigraphic forward model takes a 2D model and applies time as the third dimension to see how a reservoir or rock may change over time. The 3D geologic model is static and aims to generate a model displaying the structure and stratigraphy of an area (Blendinger et al. 2004). The benefit of a computer-generated model is that it allows for the integration of different types of data that can subsequently be updated, manipulated and changed quickly (Cancelliere et al. 2014).

Although the Illinois Basin is mature in terms of hydrocarbon development, there is a distinct lack of modern geologic research in general, and in particular there is a paucity of 3D geologic modeling of Illinois oil fields. Kimple et al. (2015) and Wagle et al. (2016) modeled the structure, stratigraphy, and porosity of Mississippian strata in the Laudon Oil Field, one of the largest and most productive oil fields in Illinois. Each of these studies used Petrel as the modeling platform. Several recent studies have used Petrel to model the structure and stratigraphy of Illinois gas storage fields (Kron et al. 2015; Peterson et al. 2015) and Quaternary glacial deposits (Hartz et al. 2016; Carlock et al. 2016a, b; Lau et al. 2016).

Stueber et al. (1993) reported on the geochemistry of formation waters and Lewan et al. (2002) and Strapoc et al. 
(2010) discussed the characteristics of the New Albany source rock. The Devonian New Albany Shale is the likely petroleum source rock in the Illinois Basin (Bethke et al. 1991; Macke 1995). Migration of $100 \mathrm{~s}$ of km is necessary to develop reservoirs in distal structures.

\section{Geologic background}

The Illinois Basin is a cratonic basin that formed as result of a failed early Cambrian rift that experienced multiple reactivations later in the Paleozoic (Leighton et al. 1990). The basin extends across much of Illinois, Indiana, Kentucky, and parts of Tennessee and Missouri. Basin boundaries include several large anticline and syncline systems on the east and west, and large fault systems in the south (Fig. 1) which are primarily a product of the ancestral Rocky Mountain orogeny (McBride and Nelson 1999). The LaSalle anticlinal belt across the eastern portion of the state is a complex system composed of multiple anticlines, synclines, monoclines, and domes that formed from the early Mississippian through the early Pennsylvanian (Clegg

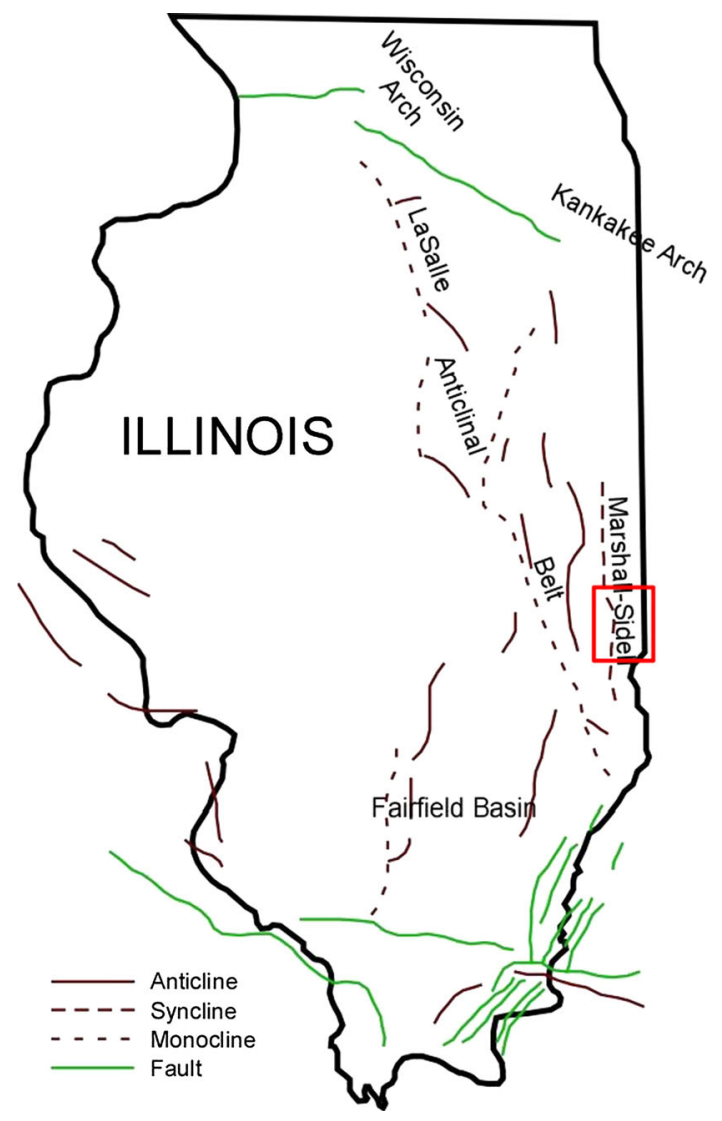

Fig. 1 Illustration showing major structures of the Illinois Basin in Illinois. The approximate location of Edgar County is outlined in red Modified from Buschbach and Kolata (1990), Kolata (2005) and Nelson (2010) 1965a; Nelson 2010). Many of anticlines in the region are tectonically inverted fault-propagation folds related to faults in the Precambrian basement (Nelson 2010).

The Basin saw the deposition of primarily carbonate rocks from the Ordovician through the middle Devonian before transitioning to the New Albany Shale group from the mid-Devonian through the early Mississippian. Early to middle Mississippian rocks are made up of numerous limestone and shale groups with a single large sandstone, the Aux Vases, in the upper middle Mississippian. Late Mississippian rocks are dominated by interbedded sandstones and mudstones. These sandstones are the reservoir rocks for much of Illinois Basin petroleum (Wagle et al. 2016). The early Pennsylvanian is marked by a major sandstone group, the Raccoon Creek Group, which is made up of the Caseyville and Tradewater Formations. The middle Pennsylvanian is represented by the Carbondale Formation which contains more than $90 \%$ of the coal reserves in the state and is some of the most heavily mined in the world (Greb et al. 2003). Upper Pennsylvanian rocks are mudstone, shale, and sandstone with thick discontinuous carbonate units (Nelson and Jacobson 2010). North of this area, the Pennsylvanian rocks thin significantly as most of the Lower Pennsylvanian is missing and the upper has been extensively eroded (Nelson 2010).

The Dudley Pool is situated across several sections of the Grandview Quadrangle in Edgar County, approximately $13 \mathrm{~km}$ west of Paris, Illinois. It is on the eastern shelf of the Illinois Basin along the edges of the La Salle Anticlinal Belt and Marshall Syncline (Clegg 1965b). The Dudley Pool straddles the Carbondale and Tradewater Formations in the Desmoinesian stage of the middle Pennsylvanian (Fig. 2). The Dudley Pool is unique in that it is among the northernmost producing fields in the Illinois Basin, and in that the units that produce are among the highest stratigraphically.

The reservoir produces from depths between 90 and $135 \mathrm{~m}$ below the surface from two discrete units, the upper Dudley sandstone and the lower Dudley sandstone, which are separated by a $20-30 \mathrm{~m}$ thick shale unit. Both sandstone units are interpreted as lenses on a monocline (Illinois State Geological Survey 2009). The lower sand is more heavily produced than the upper Dudley and has been reported to have a thickness ranging from $\sim 20 \mathrm{~m}$ in the center of the pool to as little as a meter or two on the edges of the deposit (Unpublished report by Wilson Engineering 1954).

Figure 3 shows the original structure map for the lower Dudley sandstone from Henigman Oil. The Dudley Pool was discovered in 1948 and has produced a lifetime total of nearly 4.5 million barrels through 2009 according to the Illinois Oil Field Statistics. During 2009, the 135 active wells in the field produced 59,000 barrels of oil (ISGS 


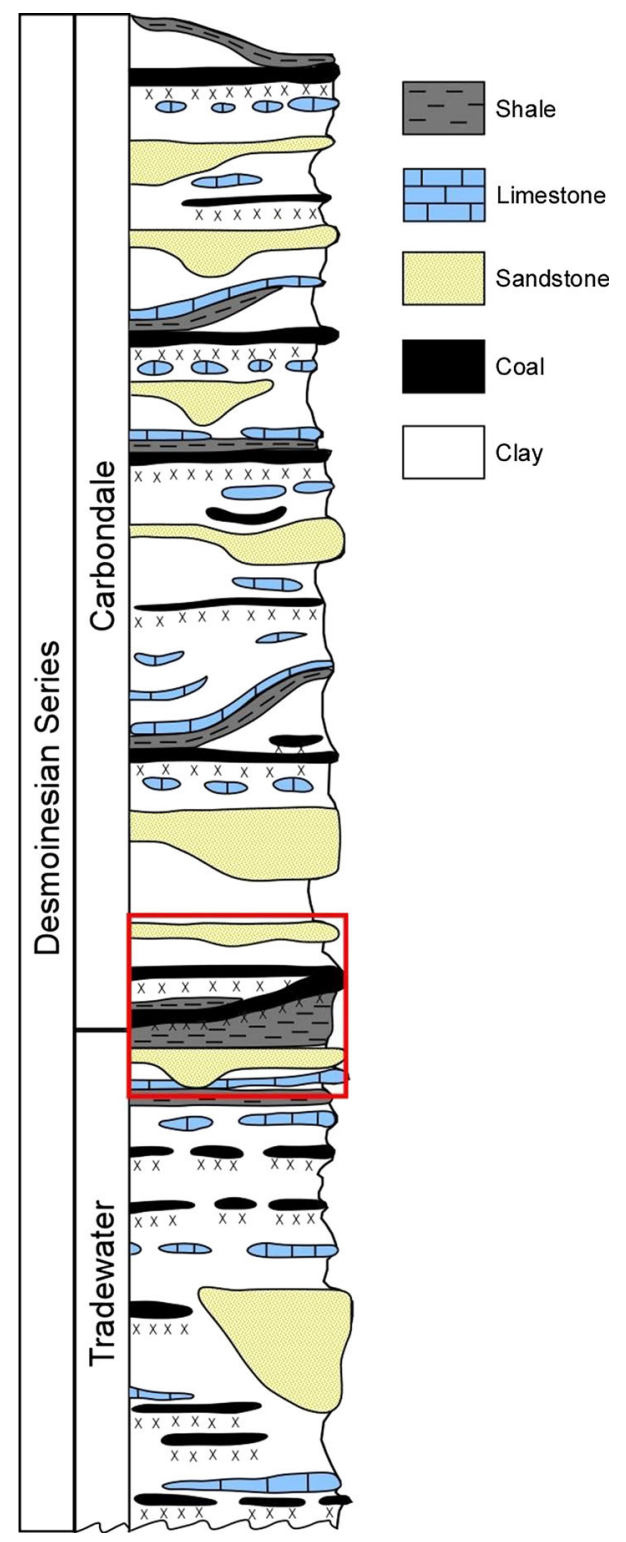

Fig. 2 Middle Pennsylvanian stratigraphic column. The stratigraphic location of the Dudley Field is boxed in red Modified from Jacobson (2002)

2009), an average of just over one barrel per day per well. Overall, there have been approximately 300 wells drilled in the Dudley Pool and in the immediate vicinity. Many of these wells were dry or not economic, but some produced gas or were drilled as injection/disposal wells.

The Henigman Oil Company currently operates 32 wells on several leases in the Dudley Field; production has steadily declined over recent years. Data from the Illinois State Geological Survey shows that production at Dudley peaked in 1995 at just over 100,000 barrels and production is currently below 60,000 barrels per year. Of the 32 active wells, five have been converted to water injection wells.
As part of the ILOIL database, the Illinois State Geological has 61 well logs from the field, which includes a combination of spontaneous potential, resistivity, gamma ray, and neutron logs. The 3D modeling and calculations were completed using Schlumberger's Petrel 2012.3, industry standard software for reservoir characterization, and has been used for similar exploration style projects (Aadil and Soahil 2014; Kimple et al. 2015; Wagle et al. 2016). The models developed in this process give an idea of the internal architecture of the reservoir, facies distribution and subsequently porosity, and volume estimates. The upper and lower Dudley sands were modeled in this project with the goal of aiding production efforts by providing Henigman Oil Co. with an interactive interpretation of the geometries of the storage field as well as volumetric calculations of recoverable oil.

\section{Methodology}

Dudley Field data, retrieved from the ISGS, included well headers and formation (well) tops from 302 wells, and downhole logs from geotechnical borings of 61 wells. Well header elements include the well's API number (a permanent, 12-digit unique identifier), latitude and longitude, farm name, total depth of the well in feet, elevation, company name, and more. Data from all wells drilled in a one mile collar of the Dudley Field extent were collected regardless of the production status of the well. The addition of data from nonproducing wells was included in an effort to make the stratigraphic and structural elements of the model as accurate and thorough as possible.

The abundance of well header information was parsed through to remove the extraneous data that was not useful for the project. Once the data had been sorted, it was reformatted into a new excel spreadsheet with each well assigned a simple numeric or alphanumeric name for ease of viewing in the modeling software. The location data were converted to $\mathrm{X}, \mathrm{Y}$ pairs in meters from an origin southwest of the field, and all depth information was converted to meters as well.

The well logs from ILOIL are the original paper logs scanned and available for download as image files. Image data are not compatible with the modeling software, and therefore, must be converted to a usable format. The logs were converted to binary digital files in Log ASCII Standard, .las, format. This was completed using the software package Neuralog. Figure 4 shows all uploaded wells on a grid with well tops and logs. The "Import on selection" command imported all .las format logs from the Neuralog folder on the computer. Using the scanned images of the well logs, lithology logs were manually "painted" onto the well logs for use in the facies modeling process later.

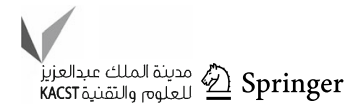


Fig. 3 Scan of the original structure map for the lower Dudley sand

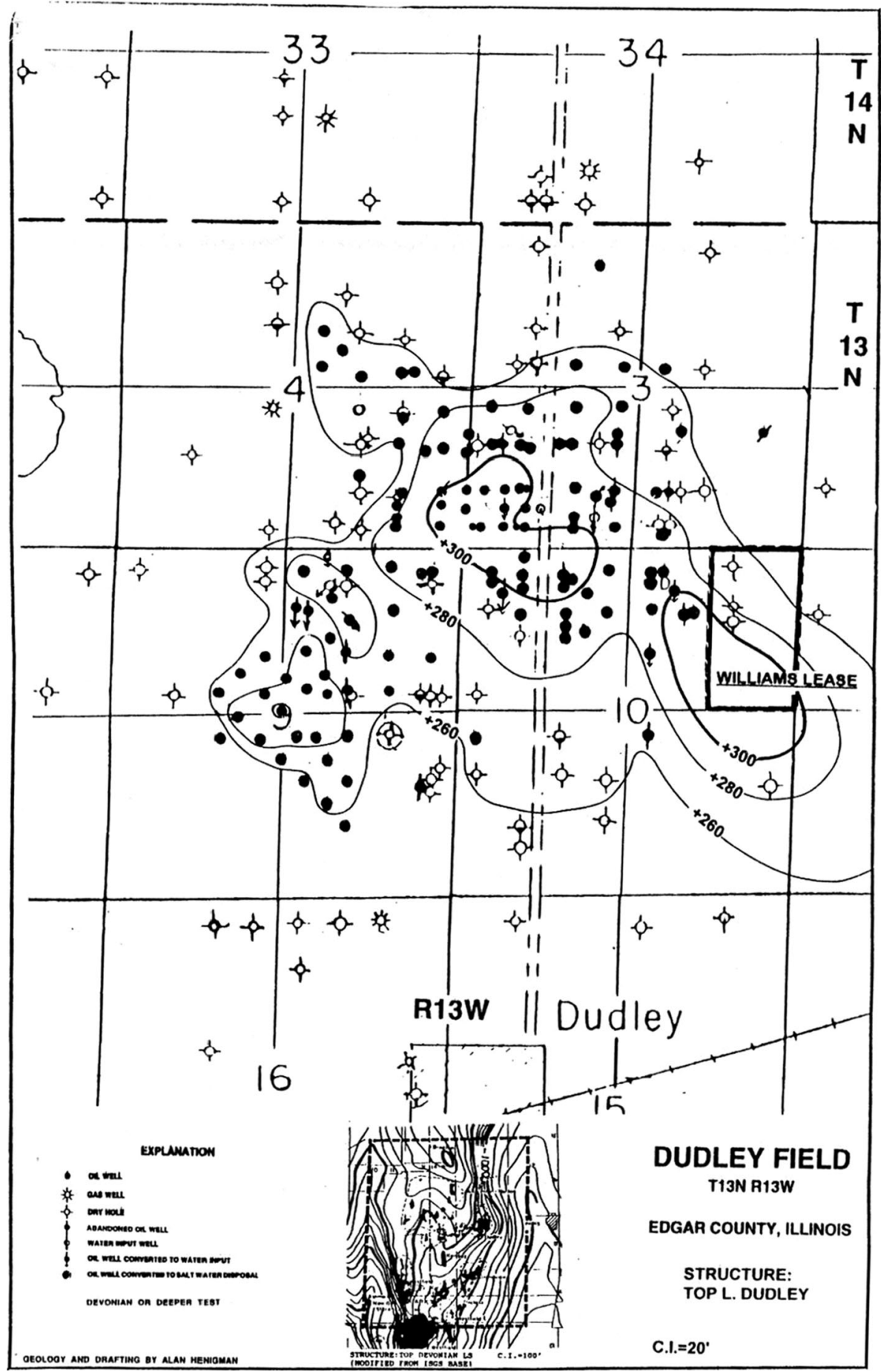

Two boundary polygons were created; one polygon, named "All Sands," contained all wells that showed Pennsylvanian sand in the driller's log, and the second only enclosed wells that showed oil, regardless of if it was a producer, and was accordingly named "Oil Sands."

The production boundary polygon and wells used through the rest of the modeling process is shows in Fig. 5 and is referenced with township, range, and section numbers. Once the domain was defined, surfaces were created. Surfaces are a 2D grid with known or interpolated depth, or $\mathrm{Z}$, data at each node on the grid; the $\mathrm{Z}$ data represent the surface. Using the "Make/edit surface" process, well tops are the main input, with the boundary defined by the polygons created previously. An attribute from the well top 


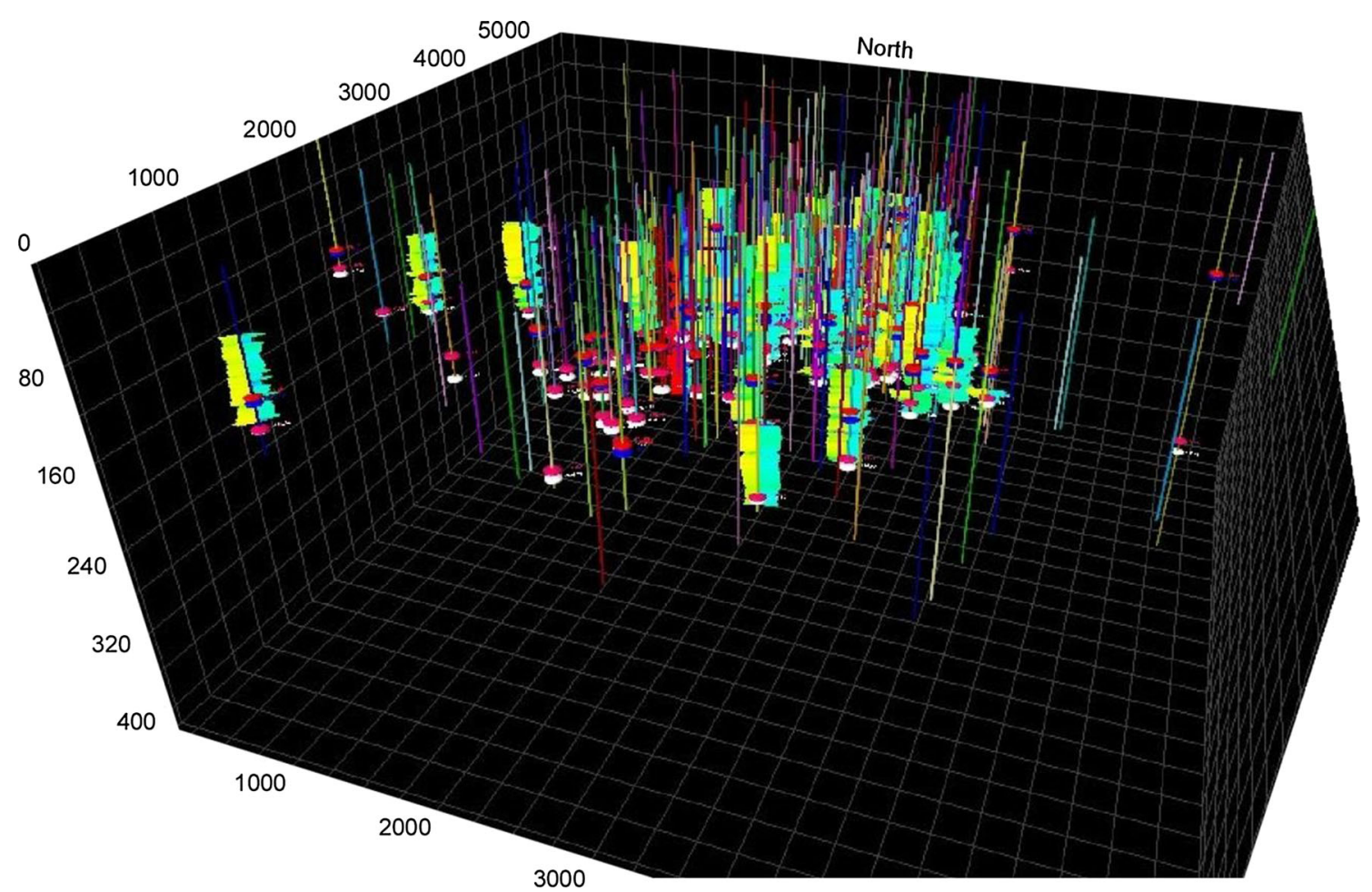

Fig. 4 Basic grid showing wells imported into the modeling software. Logs and well tops (colored discs) are displayed. $\times 7.5$ vertical exaggeration

data must be specified for mapping, depth, or Z, is used for surfaces so they are shown in the correct subsurface location.

Isochores were calculated for each zone between stratigraphic well tops from the "Convert to isochore points" command by right clicking the lower stratigraphic well tops of the zone of interest. TVT was also calculated from the well top data in the "Well settings" window. This ensures that the zone spreadsheet updates appropriately with thickness values. Isochore data were used directly to generate thickness maps.

The first step in building the 3D model is using the "Make simple grid" command. This process uses a boundary polygon and surfaces as the basis for construction of a 3D skeleton. The skeleton is composed of three layers showing the top, bottom, and middle depths of the reservoir as measured from the surfaces. This step converts the surfaces to horizons, 3D versions of the surfaces, and also builds reservoir edges that visualize how the reservoir changes around the outside. Zones are defined as the areas between surfaces, and in this project these are the upper Dudley, lower Dudley, and the area between the two sands, the upper-lower Dudley. The upper Dudley and lower Dudley zones were subdivided using the "Layering" process. The upper Dudley was divided into five layers and the lower Dudley into nine layers (Fig. 6). The layers do not have a uniform thickness, but rather run continuously across the units. This breaks the zones into significantly smaller cells that allow for heterogeneities to be realized. Each cell is $50 \mathrm{~m}$ by $50 \mathrm{~m}$ with varying thicknesses depending on its location within the layers. Each cell in the model can only have one value, and the process of upscaling averages all values in the cell to achieve one value. This was done for lithology and porosity.

The facies modeling used the upscaled lithology data and distributes these data across the area and between the wells using a selected algorithm. This step yields a threedimensional model that gives an idea of what the distribution of rock types could actually be. The modeling process can be rerun as many times as necessary to get a model that is both viable, in that it does not break any geological rules, and admissible, meaning that it conforms to previously established fact about the reservoir. The upper and lower Dudley sands were modeled while the zone between them was not as it is primarily shale and is not of interest to oil production. The first option is the choice of algorithm. Ultimately a Gaussian simulation algorithm was selected.

Cross sections were generated after the facies modeling. By opening a new well section window (WSW), a new cross section is automatically created in the input pane. While on the active WSW, the well manager spreadsheet was opened and the wells of interest for a cross section selected (Fig. 7). The order of the wells was corrected from 


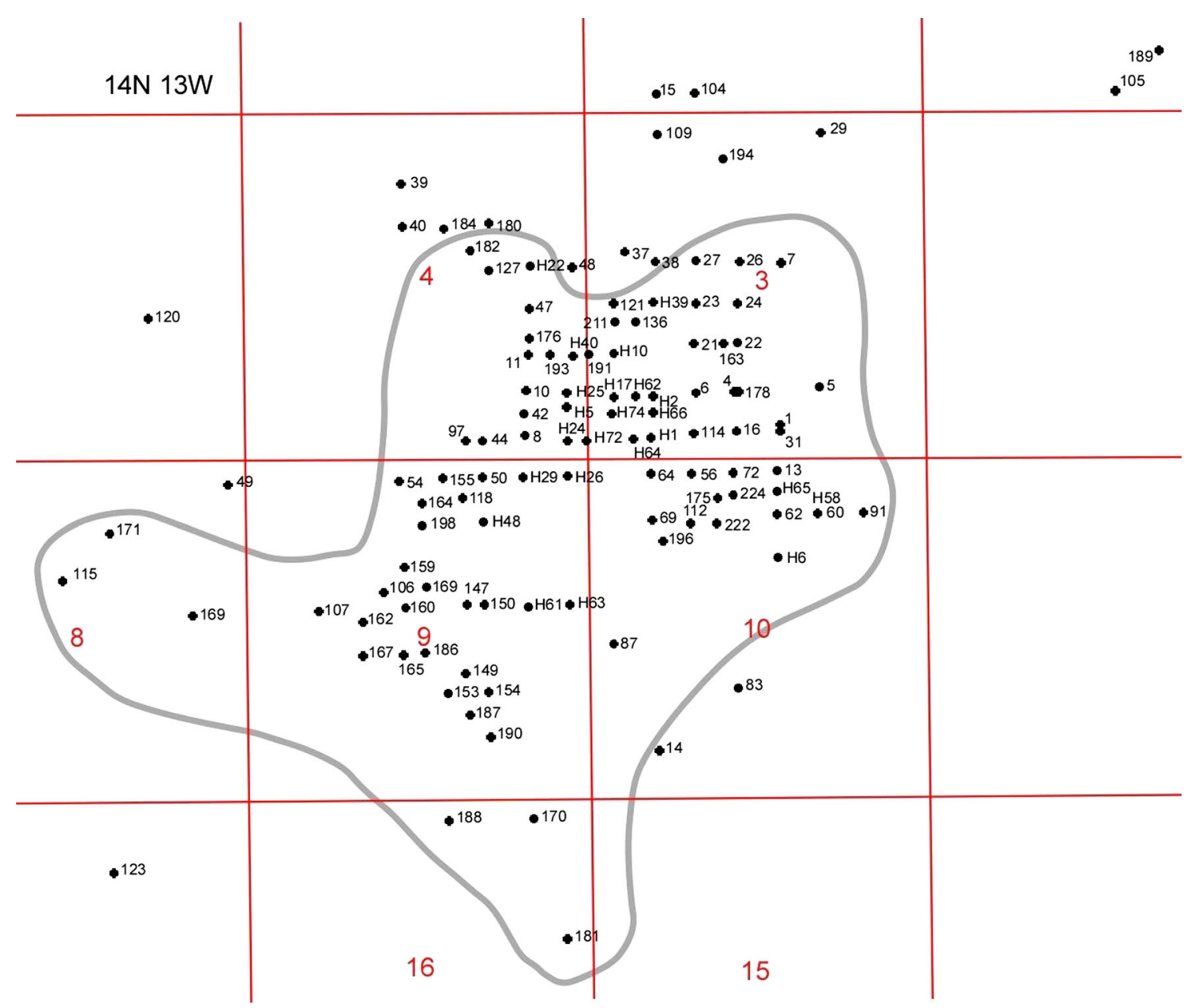

Fig. 5 Illustration showing location with relevant boundary and wells. Production boundary polygon, wells used during modeling process, and location referenced to the public land survey system are shown

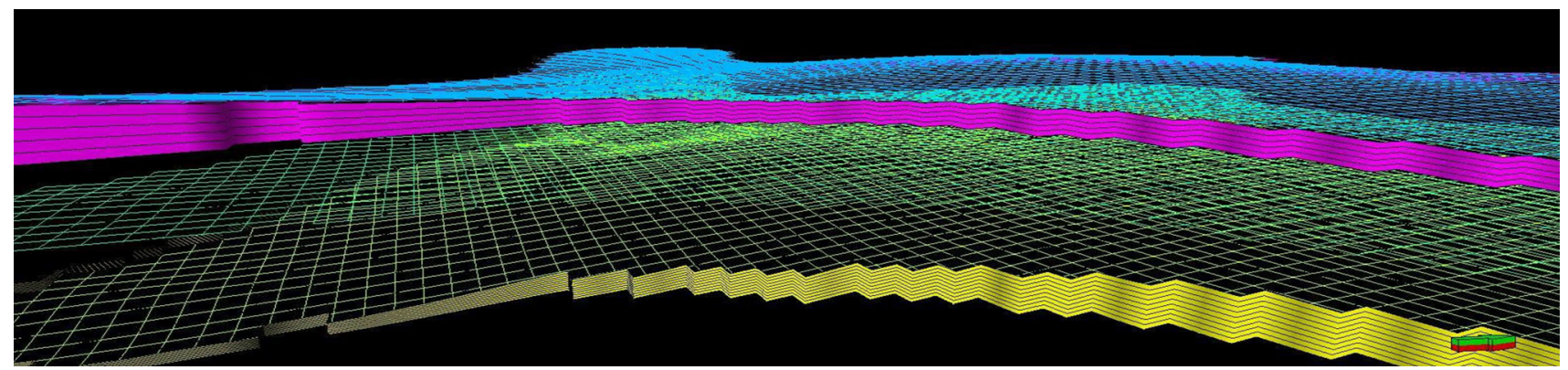

Fig. 6 Screenshot of the skeleton of the simple grid. Showing are the top (blue), middle (green), and bottom (yellow) layers of the skeleton with edges and cells. The pink-edged section is the upper Dudley

numerical order to geographic order in the settings. In a 3D window, with the cross section activated on the input pane, the option to visualize on a plane is selected, and then finally, the lithologies are turned on from the models pane.

Petrophysical modeling is the process of distributing data, in this case porosity, across the model grid. The zone, with five layers visible, and the yellow is the lower Dudley with nine layers. $\times 10$ vertical exaggeration

primary input for this step was the upscaled porosity log. Fortunately, this step allows for the model to be conditioned to the facies model. This means that porosity ranges with mean and standard deviation for each lithology. This allowed for adjustments to be made for the lack of data. Typically the system will average the values and set mean 


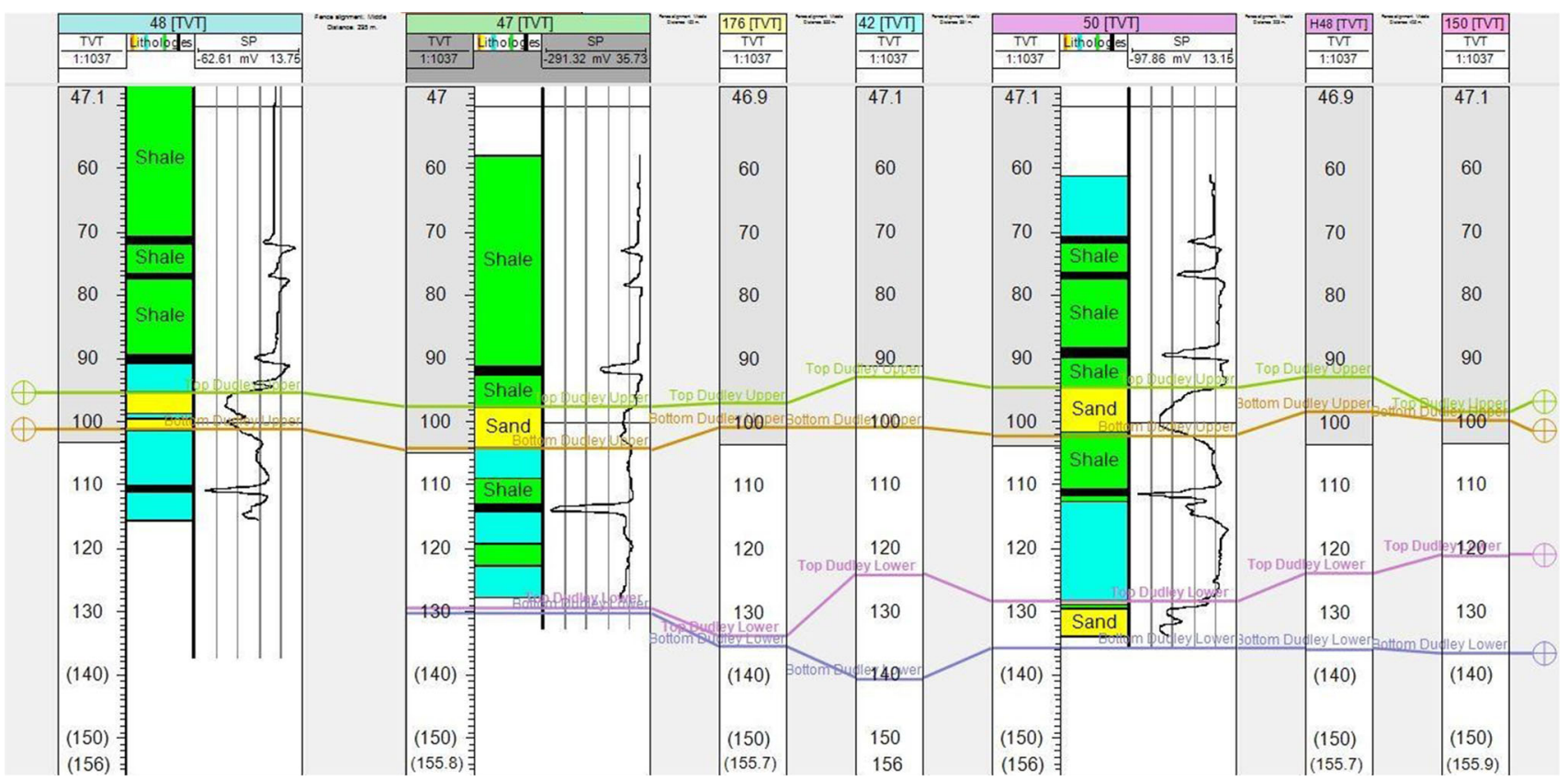

Fig. 7 Screenshot of a well section window. Three of the active wells have SP and lithology logs shown with stratigraphic surfaces correlated across the wells

Table 1 Property values used in volume calculations

\begin{tabular}{ll}
\hline Properties in oil interval & \\
Water saturation & 0.4857 \\
Oil saturation & 0.3541 \\
Gas saturation & $1-\mathrm{Sw}-\mathrm{So}$ \\
\hline
\end{tabular}

and standard deviation automatically, but with only two logs to work with, this was not possible. There were several core analysis documents available on ILOIL and those were used to set the restrictions for each lithology. By conditioning the porosity model to the facies, it ensures that the lower porosity values were seen where shale was predicted and higher values were seen with sand.

Once the 3D model is complete, volume calculations can be made. First, the oil-water contact was set at $150 \mathrm{~m}$ below the surface. Oil and water saturation values were averaged from the core analysis reports used previously for porosity ranges (Table 1). Finally, a conservative recovery factor or $30 \%$ was set, although fields under secondary recovery methods can see recovery as high as 50\% (Sandrea and Sandrea 2007). Calculations were conditioned to the facies model developed previously and run with the modeled porosity values and secondly with a set porosity of 0.181 , an average from the core analysis reports. The calculation was run twice because extensive porosity information is not available and this allows for a comparison of both sets of parameters.

\section{Results}

\section{Structure contour maps}

Structure contour maps were created from the surfaces that were generated previously to see any overall structure that dominates the reservoir. Several modeling algorithms were tested for interpolation, including Isochore Interpolation and a Gaussian function, but most gave a non-geologically feasible result with unusual dips and bumps that jump as much as $20 \mathrm{~m}$ that would be difficult to explain through geological processes. Kriging returned the most realistic surfaces apparent valleys, and ridges. Figure 8 portrays the contour map for the top of the sand of the upper and lower Dudley, respectively. The red indicates that the area is higher in the section, or closer to the land surface, and the purple is deeper for each map.

The elevation of the top of the upper Dudley sandstone ranges from less than 92 to more than $105 \mathrm{~m}$ below sea level. The highest structure is in the northeastern part of the field.

The lower Dudley sandstone top ranges in elevation from less than 122 to more than $151 \mathrm{~m}$ above sea level. The deepest part of the structure is in the southern part of the study area. At least $10 \mathrm{~m}$ of closure is evident.

\section{Isopach maps}

The upper Dudley sandstone ranges in thickness from 2 to $>12 \mathrm{~m}$, with the thickest being in the extreme southern 

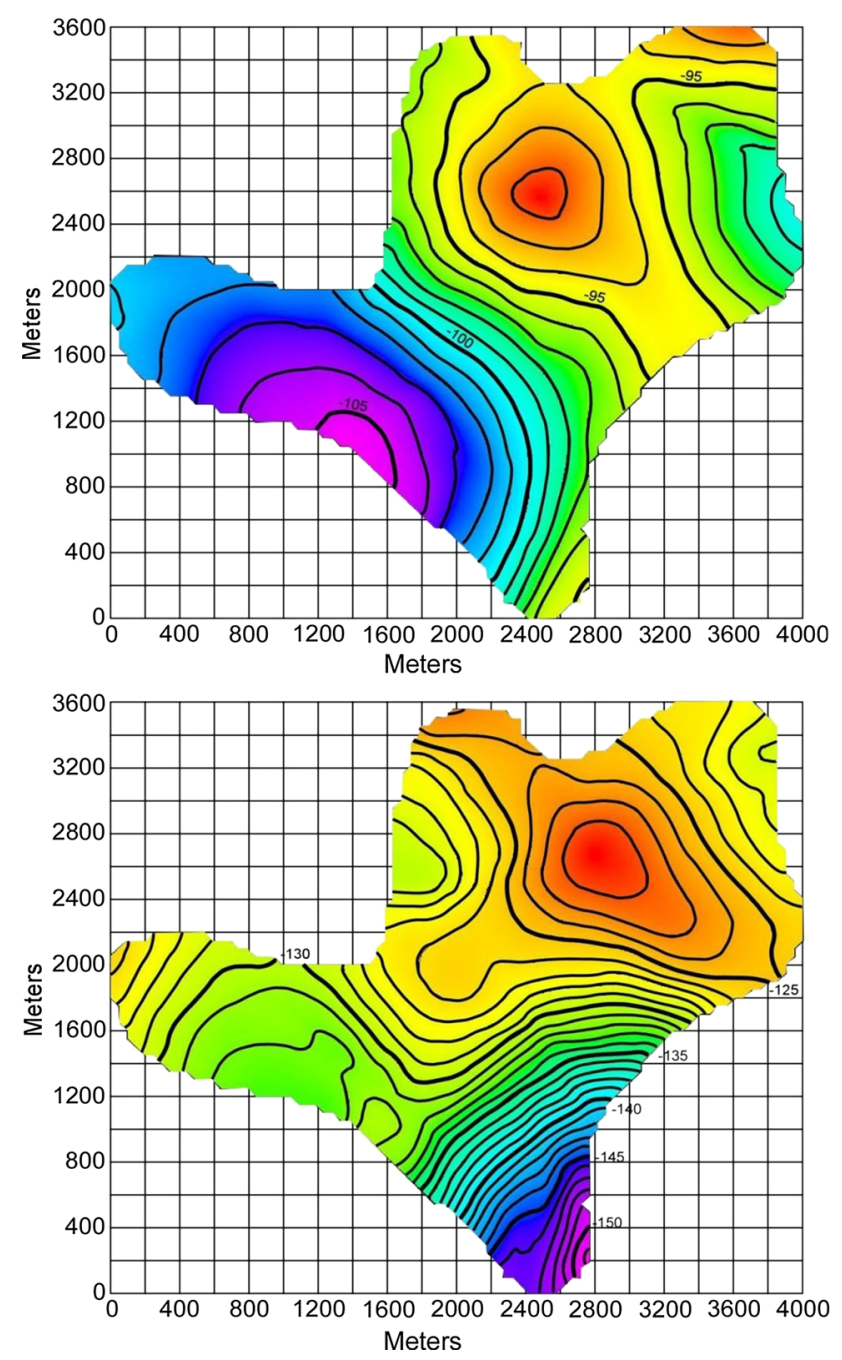

Fig. 8 Contour maps of the upper and lower Dudley sands upper (top) and lower (bottom) contour maps resulting from the Kriging algorithm

part of the study area. The unit is the thinnest in the eastern and western portions of the study area (Fig. 9). The lower Dudley sandstone has the same thickness variation, but the thickest part of the unit is in the eastern part of the study area, which also corresponds to the area of highest structure.

\section{Facies model}

By distributing the known lithology logs across the production zone, the three-dimensional model is a representation of what the reservoir sands are like and is a good visualization of potential problematic zones (Fig. 10). A Gaussian simulation algorithm was selected for the interpolation because, unlike before, Kriging generated a model with bulls-eyes around the wells because of the small amount of upscaled logs. The distribution of each
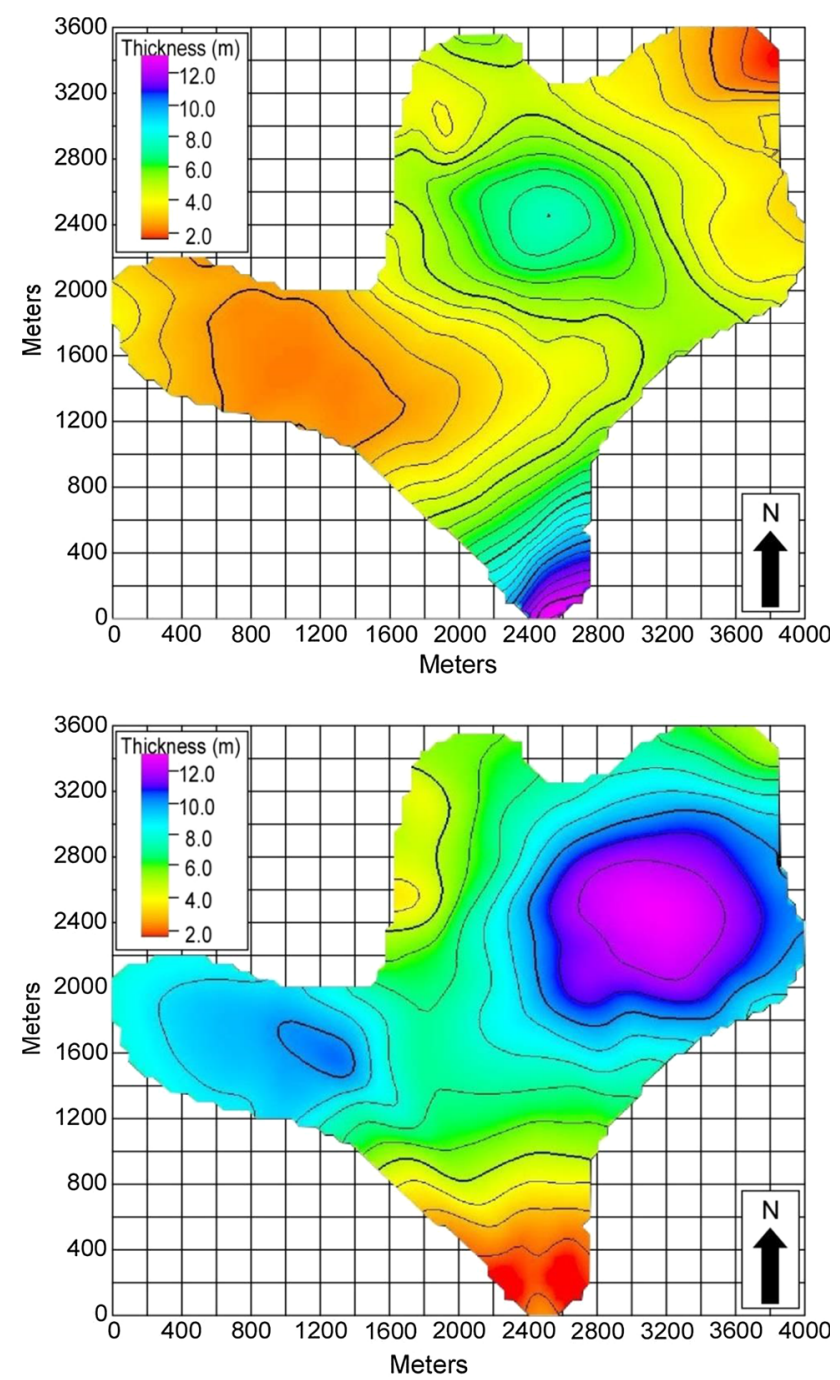

Fig. 9 Thickness maps of the upper and lower Dudley sands. The top image shows the thickness of the upper Dudley and the bottom image shows the lower Dudley

lithology is shown in Table 2; these values are generated by Petrel during the modeling process, not set by the user. Each unit is primarily sand with the upper Dudley as about $76 \%$ sand and the rest being shale or a sand-shale mixture. The lower unit has comparable values at $81 \%$ sand and the remaining $19 \%$ being shale, sandy shale, or shaley sand. In the lower Dudley, a blue and green layer can be seen from the east side that extends across the majority of the unit.

\section{Cross sections}

To determine how the upper and lower Dudley sandstones vary regionally, five cross sections were constructed. Three sections trend east-west across the reservoir and two trend north-south (Fig. 11). The northern area of the pool was emphasized in the cross sections as a quality control check 


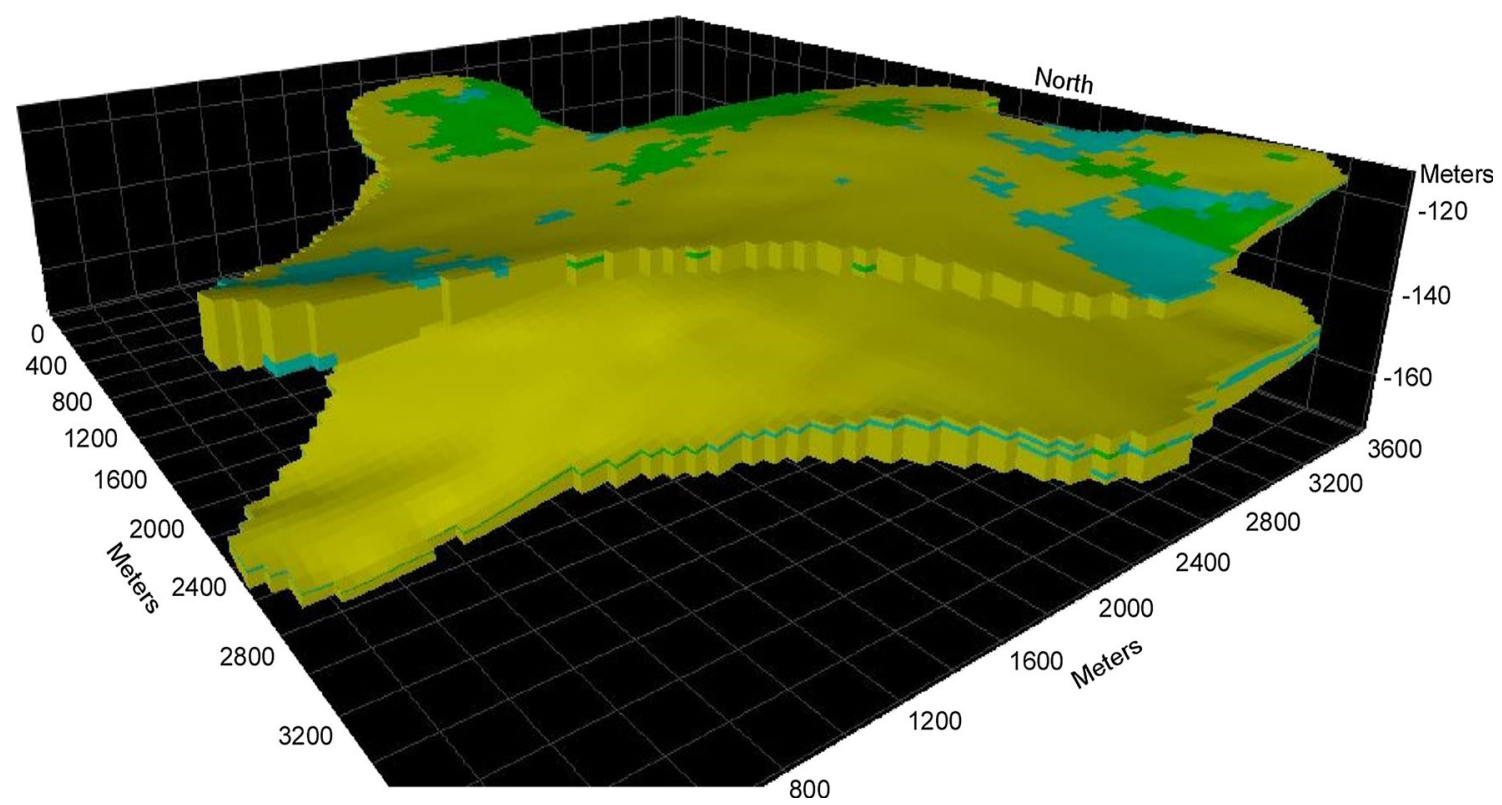

Fig. 10 Three-dimensional Facies Model of the upper and lower Dudley. Yellow represent sand, green is shale, and blue is a sand and shale mixture, i.e., sandy shale or shaley sand

Table 2 Lithology distributions from the facies model

\begin{tabular}{lll}
\hline & Upper Dudley & Lower Dudley \\
\hline Sand & 0.76 & 0.81 \\
Sand and shale & 0.10 & 0.12 \\
Shale & 0.12 & 0.07 \\
\hline
\end{tabular}

because the majority of information is concentrated in that portion of the field.

The sections between the upper and lower Dudley sands were not modeled. As before, yellow indicates sand, green is shale, and blue indicates a sand-shale mixture. The shale and sand-shale mixture decrease toward the south in the upper Dudley sand (Figs. 12, 13, 14). The lower Dudley shows similar lithology and thickness trends to that of the upper unit, with the proportion of sand increasing while thinning overall. These changes can be seen in the northsouth cross sections (Figs. 15, 16) as well but shows a thickening of the upper sand in the far south while the lower unit continues to thin.

\section{Porosity model}

The 3D petrophysical model shows an approximation of porosity distributions as controlled by the facies model. Figures 17 and 18 show how the porosity changes vertically through the layers defined 3D model setup of each the lower and upper units, respectively. The low porosity zones correspond with the shale-rich intervals of the facies model and the higher porosity with the areas that are primarily sand.

\section{Core description}

A core was selected from Clark County, just south of Edgar County, as there are no cores available from the Dudley Field. The core described is from an oil well that produces from Pennsylvanian sands that are most likely related to the reservoir investigated here. An illustration and description of the core is seen in Fig. 19.

The core shows two sand units. The upper sand begins $141 \mathrm{~m}$ below the surface, about $50 \mathrm{~m}$ deeper than at Dudley and is approximately $8.5 \mathrm{~m}$ thick, with only the upper third showing oil. The lower sand starts at 152 , or $30 \mathrm{~m}$ lower than at Dudley, is fully saturated and just under $11 \mathrm{~m}$ thick. Both sands are mica rich and show a general fining upward with the base of the each unit being more massive with coarser grains transitioning from medium to fine sand. Several intervals of flaser-bedded sandstone and siltstone were identified as well with a thin coal bed or paleosol at the top of the upper sand unit.

This core showed very distinct patterns that can be combined with the model for a more expansive analysis of the structure in the region than the model alone can offer. Estuarine deposits with flaser bedding are found on top of both of the sand units with a coal or paleosol above the upper sand. The combination of the estuarine deposits between the fining-upward sands, the organic drapes, and the consistent cross-bedding is indicative of sea-level fluctuations affecting deltaic plain deposits (Adnan and Shukla 2014; Kvale and Barnhill 1994). Volume calculations were run for two reasons. First, this was done as a quality check to see whether the model has realistic results 
Fig. 11 Map showing locations of cross sections. The area outlined in white is the area of oil production at Dudley. Cross sections lines are variably colored. Grid is in square kilometers

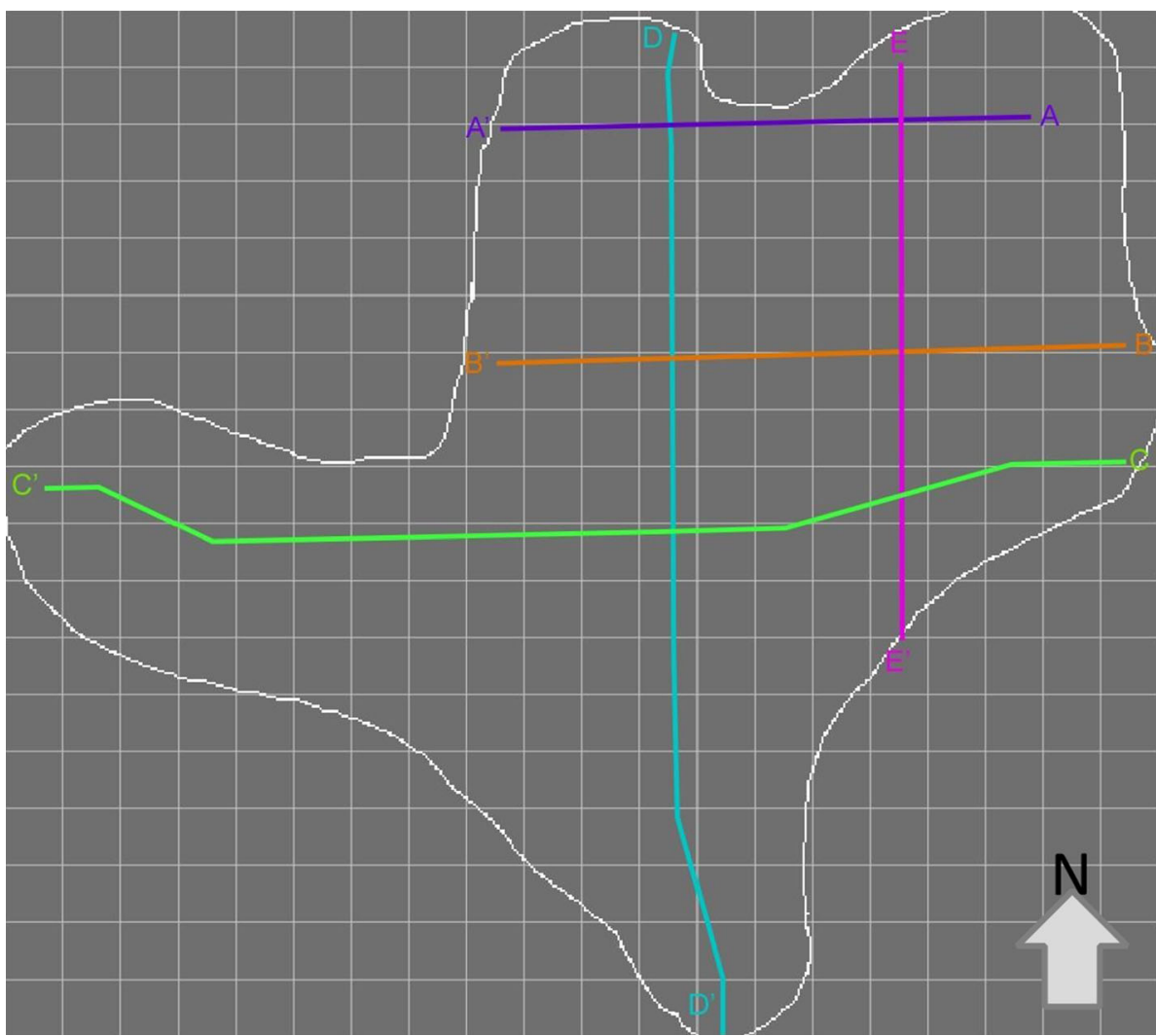

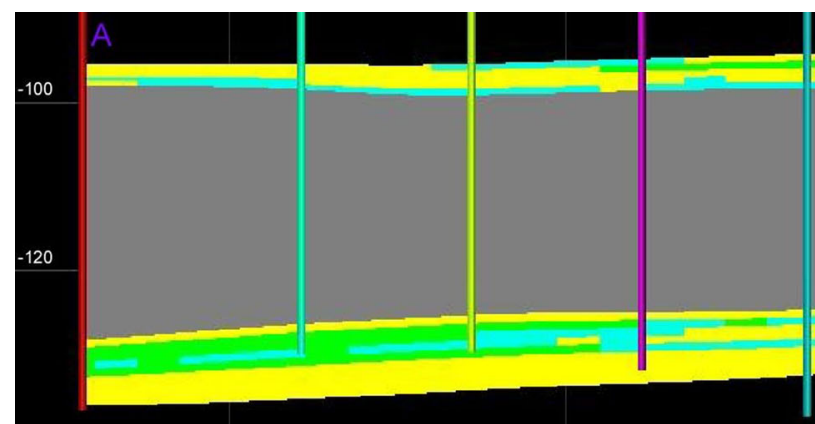

Fig. 12 Cross section $A-A^{\prime}$. East-west cross section. Depth in meters below surface. $\times 10$ vertical exaggeration. Positions of well control are indicated. The upper Dudley sand shows no systematic variation

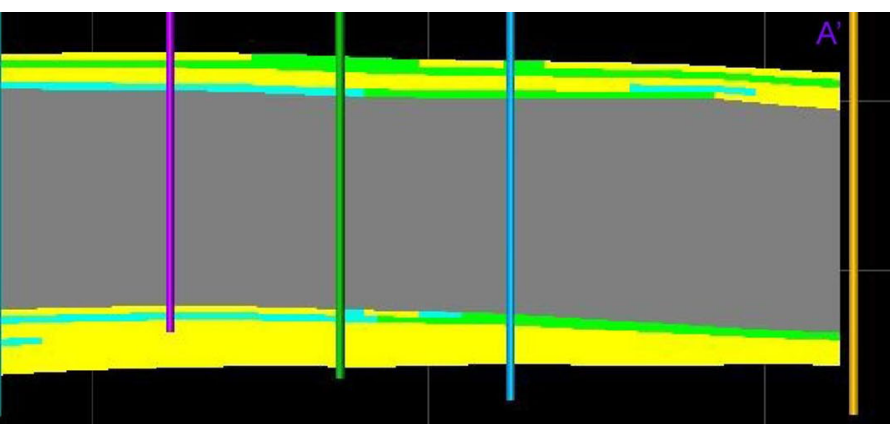

of facies or thickness. The lower Dudley sand thickness tapers to the east and tends to be sandier near the base

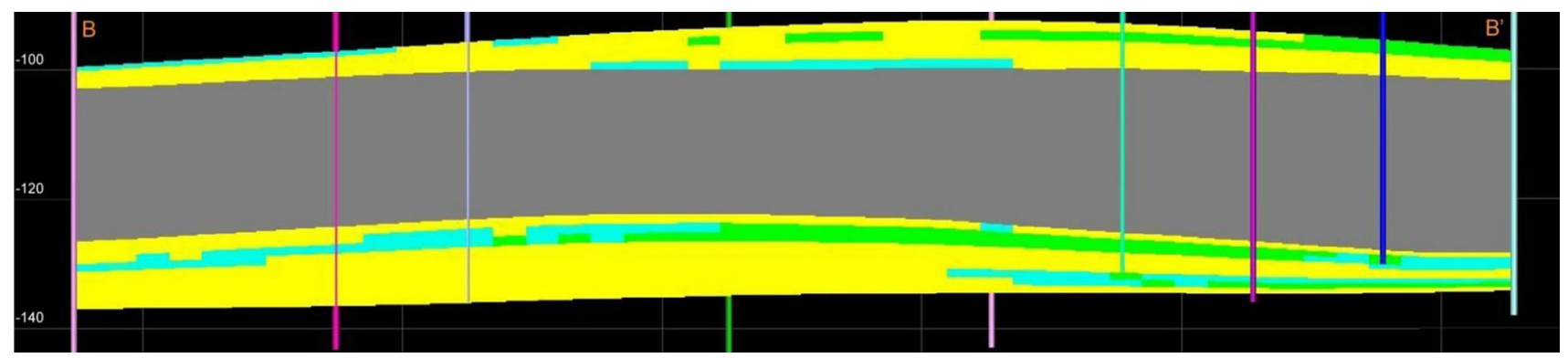

Fig. 13 Cross section $B-B^{\prime}$. East-west cross section. Depth in meters below surface. $\times 10$ vertical exaggeration. Positions of well control are indicated. Here the lower Dudley sand is again thicker and more sandy to the north. The upper Dudley sand is thickest in the center and tapers to the east and west. Interestingly, the structurally highest part of each sand is different, which may indicate differences in compaction of the intervening shaley section rather than a difference in deformational patterns 


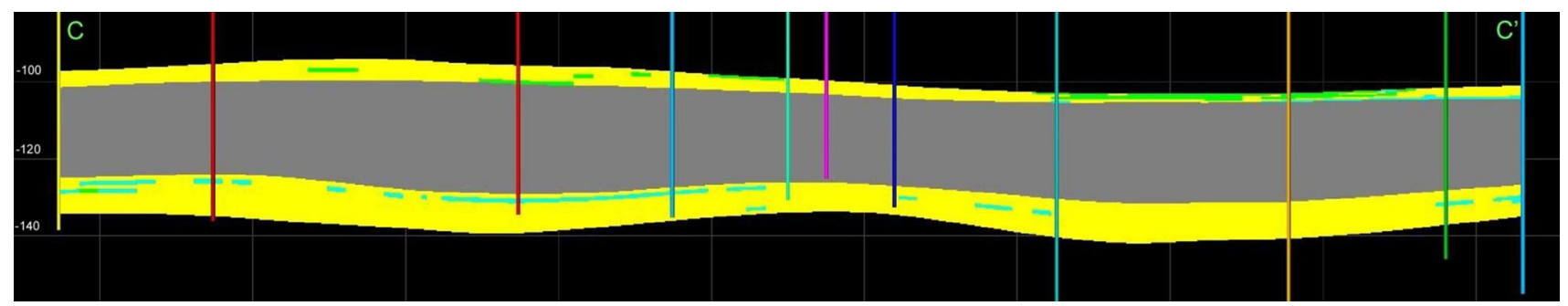

Fig. 14 Cross section $\mathrm{C}-\mathrm{C}^{\prime}$. East-west cross section. Depth in meters below surface. $\times 10$ vertical exaggeration. Positions of well control are indicated. Here the upper Dudley sand is structurally the highest in the west and tapers and becomes more shaley to the east. The structure of the lower Dudley sand is more complex and appears to be folded, but these structural complexities are more likely attributed to stratigraphic rather than structural issues

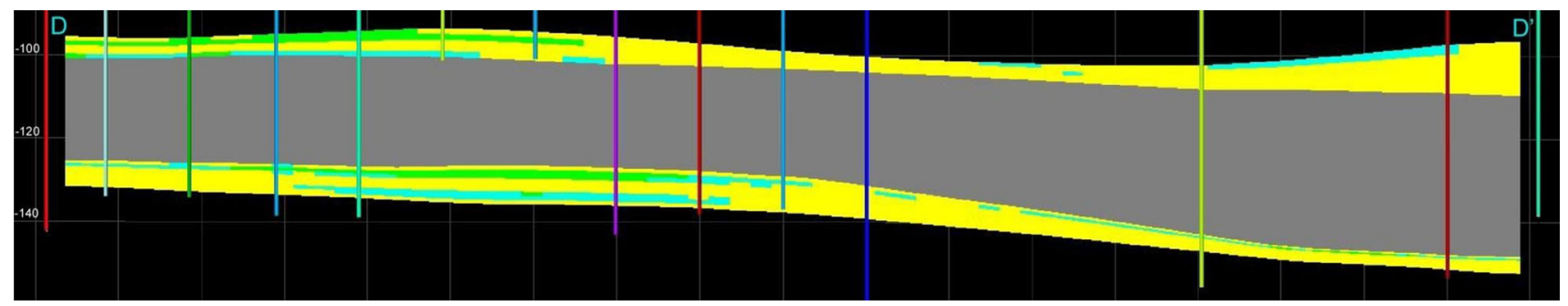

Fig. 15 Cross section D-D'. North-south cross section. Depth in meters below surface. $\times 10$ vertical exaggeration. Positions of well control are indicated. Here the upper Dudley sand has more shaley intervals to the north but becomes sandier to the south. The lower Dudley sand shows similar facies patterns, but thins significantly to the south

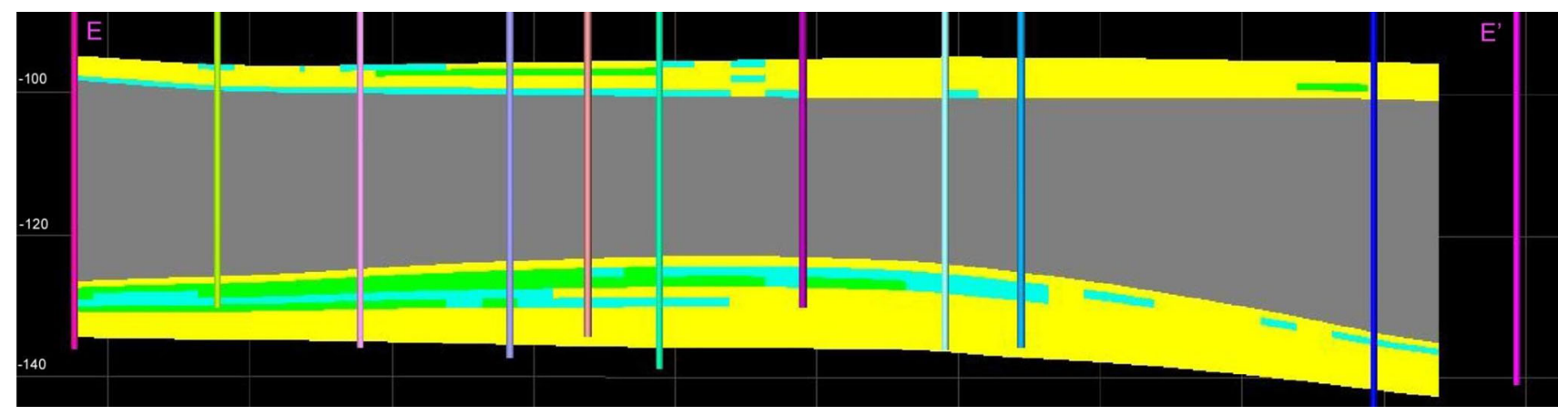

Fig. 16 Cross section E-E'. North-south cross section. Depth in meters below surface. $\times 10$ vertical exaggeration. Positions of well control are indicated. Here the upper Dudley sand is uniform in

as compared to known production of the reservoir. Secondly, the values produced will help fulfill both goals of this project in assisting Henigman Oil Co in determining future potential of the Dudley Pool but also to establish the soundness of reevaluating mature fields with Petrel or similar software.

\section{Oil volume calculations}

The oil volume calculation process was modeled twice, once using modeled porosity and once using a set porosity of 0.181. Oil in place and recoverable oil, in millions of barrels, for both processes is summarized in Table 3. The results using the modeled porosity came back slightly thickness and structure and varied little in facies. The lower Dudely sand contains significant proportions of shale to the north, but becomes sandier and thinner to the south

lower than those from the set porosity. In the end, Petrel estimates 8-9 million barrels of recoverable oil in the current extent of the Dudley Pool, including what has already been extracted. The set porosity calculation yielded slightly higher oil recovery estimations. Recoverable oil is shown in Fig. 20 for both the upper and lower Dudley sands.

\section{Interpretations and conclusions}

There were two primary goals of this project. First and foremost was to improve the understanding of oil occurrence, structure, and stratigraphy of the Dudley Pool oil 

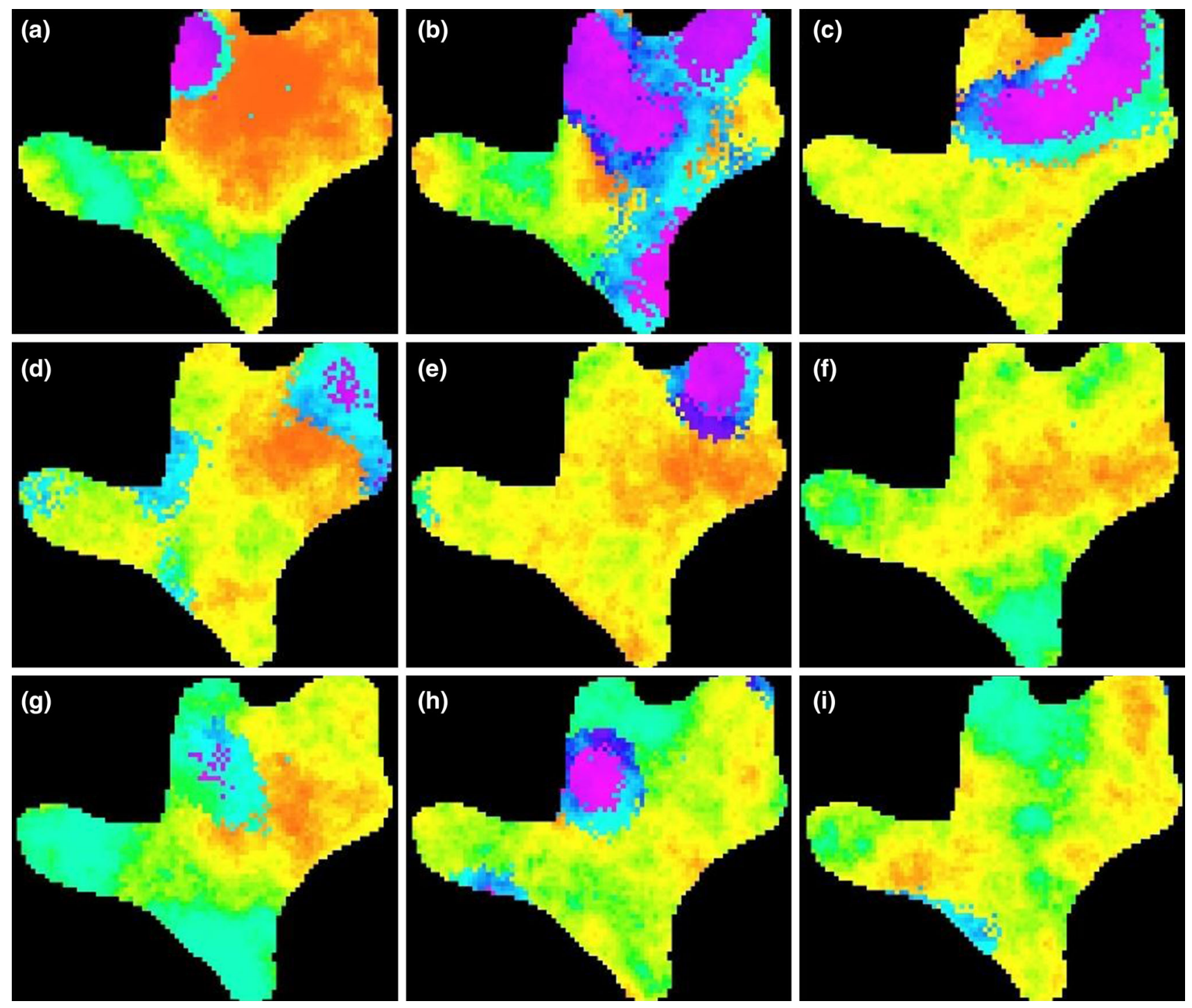

Fig. 17 Porosity of lower Dudley Layers. The nine layers of the lower Dudley sand from the top to the bottom, a through i. Red indicates high porosity, around $20 \%$, and purple is low porosity, $\sim 2 \%$

reservoir. This information will be offered to Henigman Oil Company to assist in production of the reservoir. The second objective was to determine whether three-dimensional modeling is a worthwhile tool for evaluating mature oil fields with limited and/or poor-quality data. A 3D model of the pool was created using Schlumberger's Petrel 2012.3 that offers insight into the governing structures and lithologic distribution within the field, and to generate new volume calculations through porosity modeling. The usefulness of modeling in this type of scenario is discussed by a comparison of the resulting model with the original maps, the potential value to an operator, and a company's accessibility to the tool.

\section{The Dudley pool}

The core that was described shows very distinct patterns that can be combined with the Petrel model for a more expansive analysis of the structure in the region than the model alone can offer. Estuarine deposits with flaser bedding are found on top of both of the sand units with a coal or paleosol above the upper sand. The combination of the estuarine deposits between the fining-upward sands, the organic drapes, and the consistent cross-bedding is indicative of sea-level fluctuations affecting deltaic plain deposits (Adnan and Shukla 2014; Kvale and Barnhill 1994). 
Fig. 18 Porosity of upper Dudley Layers. The five layers of the upper Dudley sand from the top to the bottom, a through e. Red indicates high porosity, around $20 \%$, and purple is low porosity, $\sim 2 \%$
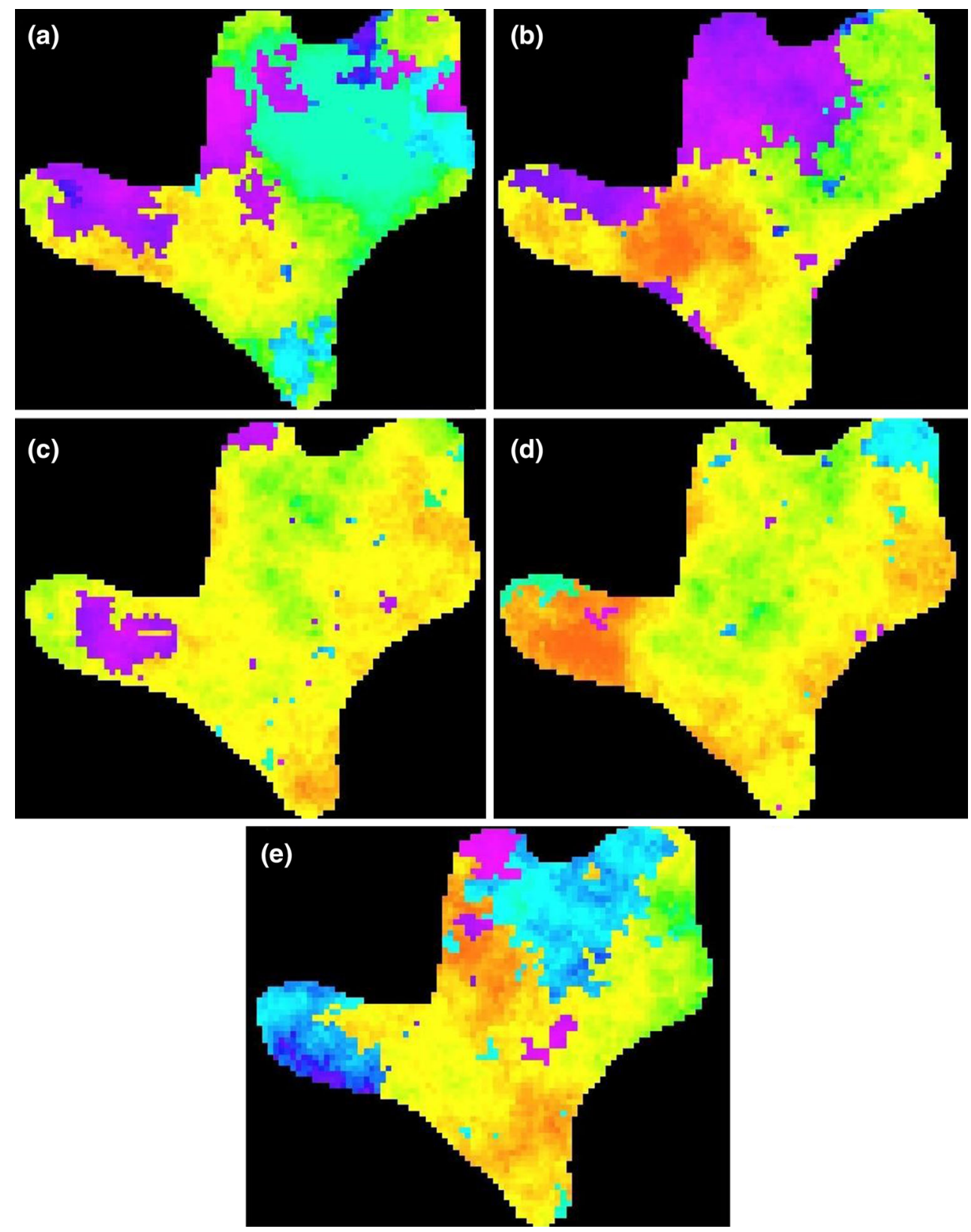

Review of the thickness maps generated by Petrel shows that the thickest sands of the upper Dudley follow a north to southeast trend. The southern portion of the upper Dudley is unusually thick and contrary to what is known of the field, as such, potential for error in the model will be discussed later. The thickest sand of the lower Dudley trends from northeast to west. These directional trends suggest that the Dudley sands could be channel deposits. Considering that the core shows a deltaic signature, combined with apparent channel forms, we believe that the upper and lower Dudley sands are part of a previously identified extensive channel system that is positioned in a northeast-southwest direction toward the interior of the basin (ISGS 2000). If the Dudley sands are not simply lenses but channel deposits, they might be able to be exploited elsewhere.

The lithologic distribution from the 3D model shows that the units are primarily sand with $\sim 20 \%$ shale or sandshale mixture scattered throughout the reservoir. The upper Dudley sands exhibit good continuity across the field without any significant disruption from the shale layers. The shale appears in several layers across the top and bottom of the unit primarily concentrated in the northern portion of the reservoir, which also happens to be the best producing. The lower Dudley shows considerable shale accumulation in the northern section as well. As discussed 


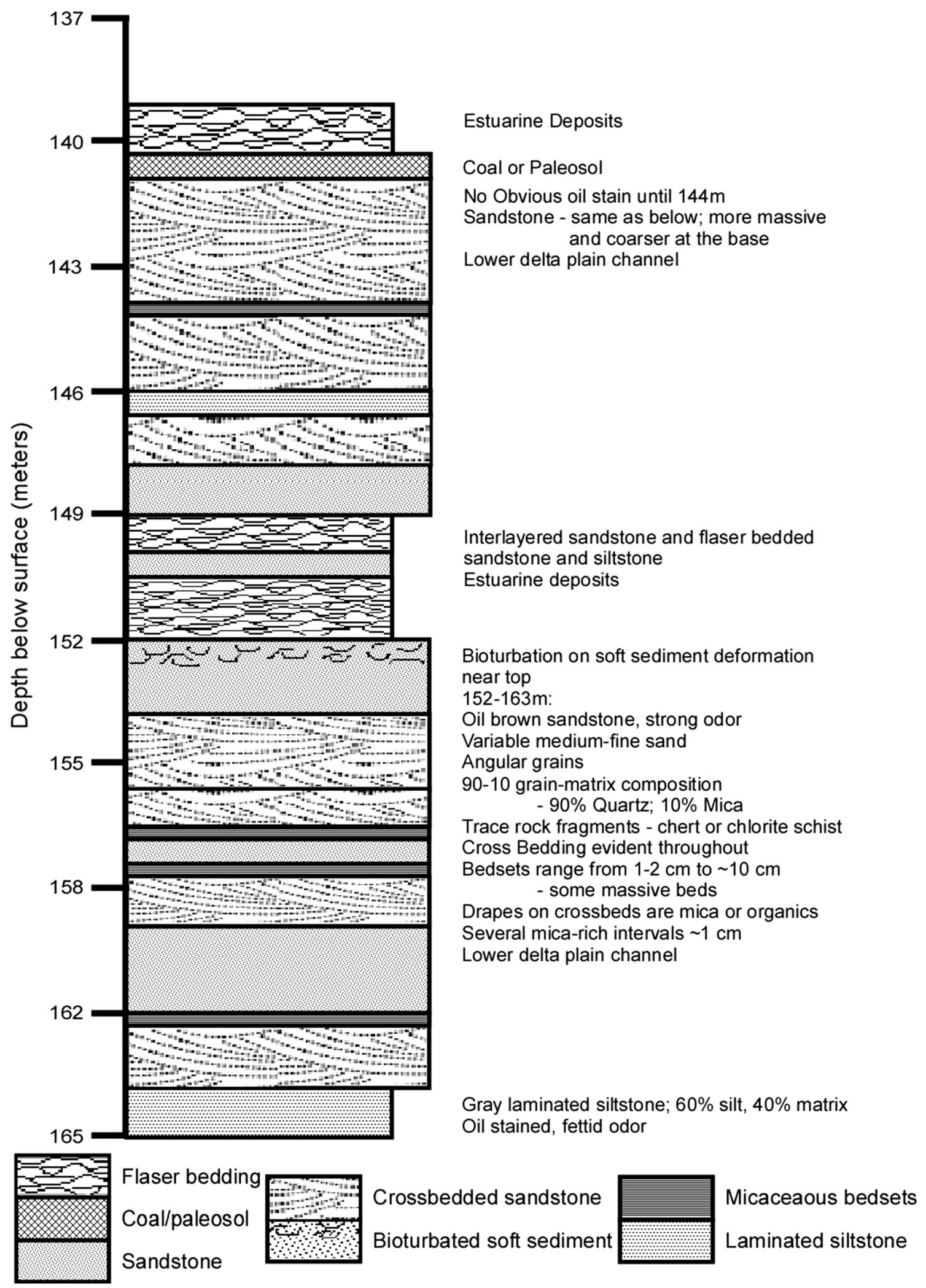

Fig. 19 Illustration of the description for core C-14055 from Clark County, IL 
Table 3 Results from volume calculation process (in millions of barrels)

\begin{tabular}{llllll}
\hline & \multicolumn{2}{l}{ Modeled porosity } & & & \multicolumn{2}{l}{ Porosity $=0.181$} \\
\cline { 2 - 3 } & Oil in place & Recoverable & & Oil in place & Recoverable \\
\hline Upper Dudley sand & 9.2 & 2.8 & & 10.1 & 3.0 \\
Lower Dudley sand & 17.2 & 5.2 & & 18.9 & 5.7 \\
Total sand & 26.4 & 7.9 & 29.1 & 8.7 \\
\hline
\end{tabular}
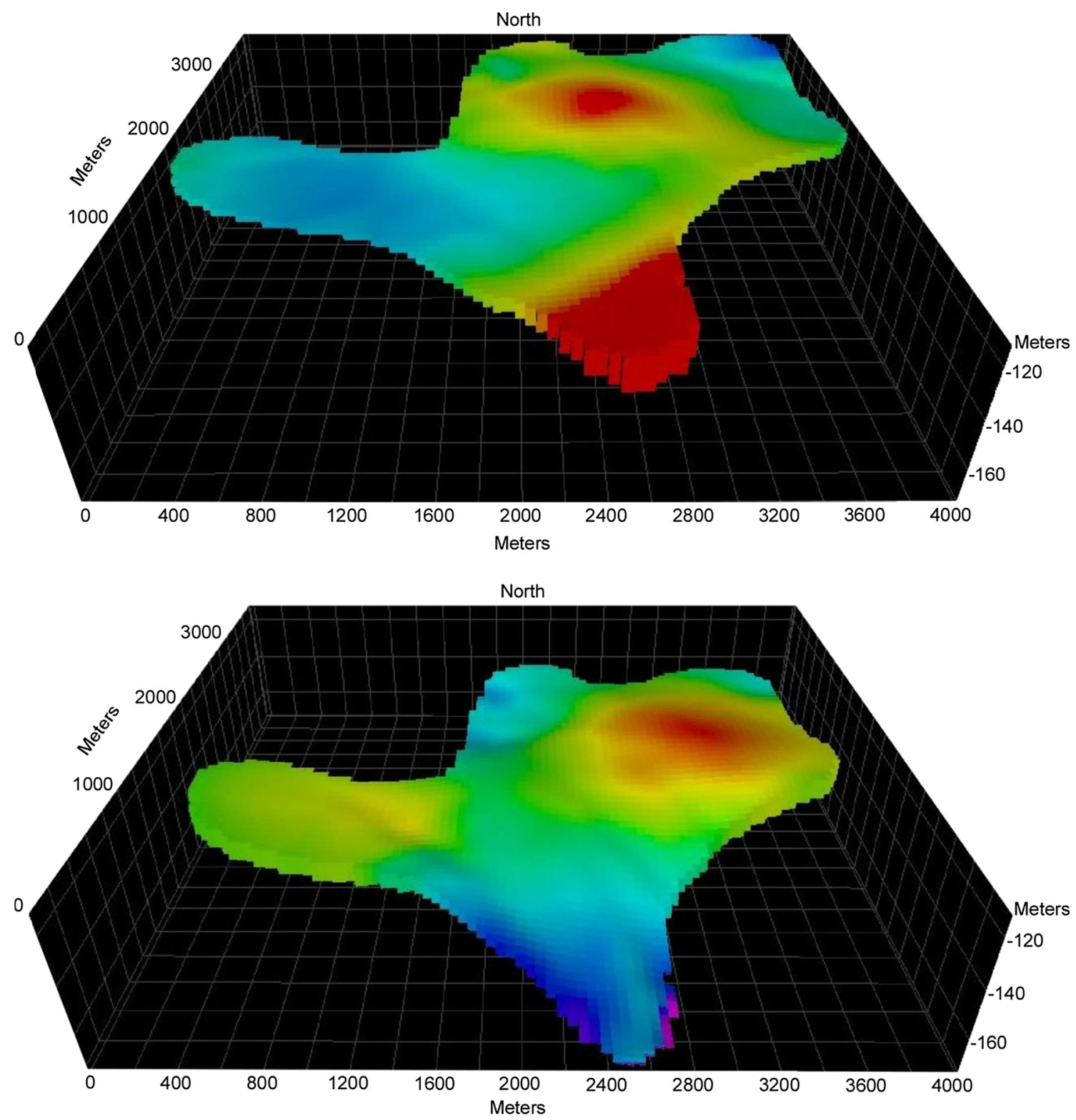

Fig. 20 Map of recoverable oil in the upper and lower Dudley. Oil presence of the upper Dudley (top) and lower Dudley (bottom) is shown in relative scale, with red indicating a higher amount of oil recoverable and blue indicating less

in the introduction, the shale in the lower unit separates the sand into two sub-units. The shale bedding appears to reach all but the southern extent of the reservoir, unlike previously thought. Toward the south the sand thins with considerably less shale, possibly pinching out beyond the field's production limit.

The porosity model was conditioned to the lithology distribution of the facies model; thus, the predicted 
porosities follow the patterns seen in that model. The porosity was used to directly calculate volumes for the reservoir. As seen in Table 3, the volume calculations indicate that there may be two million or more barrels of recoverable oil in the Dudley Pool, even considering the uncharacteristic thickness in the southern upper Dudley. As expected, the north-central region where Petrel distributed thicker sand and higher porosities resulted in more recoverable oil, and the areas with shale show significantly less oil present.

\section{D modeling for mature fields}

To determine whether three-dimensional modeling is a reasonable method for reevaluating mature fields, especially those without extensive or high-quality data available, I took into consideration three things: the quantity and quality of the information generated, the potential value to the operator, and accessibility to the tool.

There is very little information with which to compare the Petrel models, which is largely the purpose behind the project. The Dudley Pool has two original sets of maps, a structure map and a thickness map for each unit, discussed in the introduction. A simple side-by-side comparison shows that the new contour and structure maps follow the same directional trends seen on the originals. This demonstrates that the process will generate viable and admissible interpretations of the reservoir. The new contour and thickness maps also show that the sand units continue beyond the production area and may indicate possible new areas that could be exploited, i.e., reserve additions. Much of the additional information achieved through this process, such as the cross sections and volume calculations, could be produced by hand, but the ease at which the 3D model can be manipulated and edited offers a different type of value, one of convenience. The biggest impediment is the accessibility to the modeling software. If a company does not have the resources to purchase a modeling software package, they must rely on willing graduate students or hire a consultant.

\section{Conclusions}

This project involved a multi-step Petrel model that resulted in the generation of contour maps, thickness maps, a facies model, five cross sections (with unlimited more possible), a porosity model, and updated volume calculations of the Dudley Pool in Eastern Illinois. These components were designed to improve understanding of this mature oil field in an attempt to assist Mr. Gary Henigman of Henigman Oil Co. in his production and management of the reservoir. This project was also completed to evaluate three-dimensional modeling as an effective method for reexamining mature oil fields.

The Dudley Pool is part of major channel system heading from the north toward the interior of the Illinois Basin. The thicker lower Dudley unit continues to the north-northeast and could be explored for additional petroleum resources. The porosity model and volume calculations indicate that there are upwards of two million or more barrels of recoverable oil in the reservoir. However, expectations should be that production will not increase in terms of barrels per day due to the asymptotic relationship between field age and production as shown by Abbaszadeh et al. (2014).

There is inevitably error in the model, as seen with the unusual thickening of the upper Dudley unit. By definition, models rely on many assumptions, and error is thus inherent. Since I hand-picked many of the well tops before the modeling process even began, if a unit was identified or entered into Petrel incorrectly, it would only propagate through the rest of the modeling process. The software relies on the data entered, but each step requires additional assumptions which may compound error.

This project is meant to provide insight into a complicated issue. It also demonstrates that modern technology, such as Petrel, can be applied in situations where only limited or poor-quality data are available. The usefulness of this methodology is apparent, despite the hurdles discussed, as new directions of exploration could emerge or calculated reserves in the modeled reservoir may increase. Any additional reserves are significant, as they may assuage a decline in production.

Determining the future production potential of a mature oil field is a complex geologic and economic problem. The use of modern technologies and software facilitates the development of high-quality results that lead to a better understanding of a reservoir. Ultimately, we would recommend this process for reevaluating a field, even with limited data.

Acknowledgements We would like to thank Mr. Gary Henigman of Henigman Oil Company for his assistance and interest in the project. We want to thank Schlumberger for gifting Petrel to the GeographyGeology Department at Illinois State University, the department for support through a teaching assistantship and the Department of Geography-Geology for Powell Fund for software training in Houston. The wonderful scientists at the Illinois State Geological Survey provided excellent help throughout the process.

Open Access This article is distributed under the terms of the Creative Commons Attribution 4.0 International License (http:// creativecommons.org/licenses/by/4.0/), which permits unrestricted use, distribution, and reproduction in any medium, provided you give appropriate credit to the original author(s) and the source, provide a link to the Creative Commons license, and indicate if changes were made. 


\section{References}

Aadil N, Soahil GM (2014) 3D geological modeling of Punjab Platform, Middle Indus Basin Pakistan through integration of wireline logs and seismic data. J Geol Soc India 83:211-217

Abbaszadeh A, Bresch D, Desjardins B, Grenier E (2014) Asymptotic production behavior in waterflooded oil reservoirs: decline curves on a simplified model. Eur J Mech B-Fluids 43:131-134

Adnan A, Shukla UK (2014) A case of normal regression with sea level transgression: example from the Ganurgarh Shale, Vindhyan Basin, Maihar Area, MP, India. J Geol Soc India 84(4):406-416

Bethke CM, Reed JD, Oltz DF (1991) Long-range petroleum migration in the Illinois Basin. Am Assoc Pet Geol Bull 75(5):925-945

Blendinger W, Brack P, Norborg AK, Wulff-Pedersen E (2004) Three-dimensional modelling of an isolated carbonate buildup (Triassic, Dolomites, Italy). Sedimentology 51(2):297-314

Buschbach TC, Kolata DR (1990) Regional setting of Illinois Basin: chapter 1: part I. Illinois Basin: regional setting. In: Leighton MW, Kolata DR, Oltz DT, Eidel JJ (eds) M 51: interior cratonic basins. American Association of Petroleum Geologists, Tulsa, pp 29-55

Cancelliere M, Viberti D, Verga F (2014) A step forward to closing the loop between static and dynamic reservoir modeling: oil and Gas. Sci Technol 69(7):1201-1225

Carlock E, Peterson EW, Malone DH (2016a) Three-dimensional geologic modeling and groundwater flow modeling above a $\mathrm{CO}_{2}$ sequestration test site. Open J Mod Hydrol 6:182-193

Carlock DC, Thomason JF, Malone DH, Peterson EW (2016b) Stratigraphy and extent of the Pearl-Ashmore Aquifer, McHenry County, IL, USA. World J Environ Eng 4:6-16

Clegg KE (1965a) The La Salle Anticlinal Belt and adjacent structures in east-central Illinois. Ill Acad Sci Trans 58(2):82-94

Clegg KE (1965b) Subsurface geology and coal resources of the Pennsylvanian system in Clark and Edgar counties, Illinois. Illinois State Geological Survey, Cir 380

Greb SF, Andrews WM, Eble CF, DiMichele W, Cecil CB, Hower JC (2003) Desmoinesian coal beds of the Eastern Interior and surrounding basins: the largest tropical peat mires in Earth history. In: Chan MA, Archer AW (eds) Extreme depositional environments. Geological Society of America, Special Paper 370, pp 127-150

Hartz MA, Malone DH, Nelson RS (2016) Three-dimensional modeling of a glacial Valley Train outwash deposit using twodimensional seismic refraction techniques. Geosciences 6:1-15

Illinois State Geological Survey (2000) Depositional history of the Pennsylvanian rocks in Illinois: Geonotes 002

Illinois State Geological Survey (2009) Illinois oil field statistics. http://isgs.illinois.edu. Accessed Aug 2014

Jacobson R (2002) Pennsylvanian stratigraphic column. Illinois State Geological Survey, Champaign, IL

Kimple D, Peterson EW, Malone DH (2015) Stratigraphy and porosity modeling of southern centeral Illinois Chester (Upper Missisippian) series sandstones. World J Environ Eng 3:82-86
Kolata DR, compiler (2005) Bedrock geology of Illinois. Illinois State Geological Survey, Illinois Map 14, 1:500,000

Kron NA, Malone DH, Peterson EW (2015) Three-dimensional geologic model of the Pecatonica gas storage field, Winnebago County, IL. World J Environ Eng 3:121-125

Kvale EP, Barnhill ML (1994) Evolution of lower Pennsylvanian estuarine facies within two adjacent paleovalleys, Illinois Basin, Indiana. In: Dalrymple RW, Boyd R, Zaitlin B (eds) Incisedvalley systems: origin and sedimentary sequences. SEPM special publication 51, pp 191-207

Lau J, Thomason JF, Malone DH, Peterson EW (2016) Modeling the sediment fill of the upper Troy Pre-Glacial Bedrock Valley, McHenry County, Illinois, USA. J Geosci Environ Prot 4:107-122

Leighton MW, Kolata DR, Oltz DT, Eidel JJ (1990) M 51: interior cratonic basins. American Association of Petroleum Geologists

Lewan MD, Henry ME, Higley DK, Pitman JK (2002) Materialbalance assessment of the New Albany-Chesterian petroleum system of the Illinois basin. Am Assoc Pet Geol Bull 86(5):745-778

Macke DL (1995) Illinois Basin Province (064). In: Gautier DL, Dolton GL, Takahashi KI, Varnes KL (eds) 1995 National assessment of United States oil and gas resources-results, methodology, and supporting data. US Geological Survey Digital Data Series 30

McBride JH, Nelson WJ (1999) Style and origin of mid-Carboniferous deformation in the Illinois Basin, USA-Ancestral Rockies deformation? Tectonophysics 305(1-3):249-273

Nelson WJ (2010) Structural features. In: Kolata DR, Nimz CK (eds) Geology of Illinois. Illinois State Geological Survey, Champaign, IL, pp 90-104

Nelson WJ, Jacobson RJ (2010) Pennsylvanian subsystem and Permian system (Absaroka Sequence). In: Kolata DR, Nimz CK (eds) Geology of Illinois. Illinois State Geological Survey, pp 187-205

Peterson EW, Martin LI, Malone DH (2015) Identification of potential vertical gas migration pathways above gas storage reservoirs. World J Environ Eng 3:23-31

Sandrea I, Sandrea R (2007) Recovery factors leave vast target for EOR technologies. Oil Gas J 105(41):44-47

Strapoc D, Mastalerz M, Schimmelmann A, Drobniak A, Hasenmueller NR (2010) Geochemical constraints on the origin and volume of gas in the New Albany Shale (Devonian-Mississippian), eastern Illinois Basin. Am Assoc Pet Geol Bull 94(11): 1713-1740

Stueber AM, Walter LM, Huston TJ, Pushkar P (1993) Formation waters from Mississippian-Pennsylvanian reservoirs, Illinois basin, USA: chemical and isotopic constraints on evolution and migration. Geochim et Cosmochim Acta 57(4):763-784

Wagle JS, Malone DH, Peterson EW, Tranel LR (2016) Porosity controls upon secondary recovery success at the Laudon field, South-Central, Illinois. Interpretation 4(1):1-13

Wilson BL (1954) Engineering study: secondary recovery possibilities Dudley Pool, Edgar County, Illinois. Wilson Engineering, Mt. Vernon 